\title{
LEGAL ASPECTS OF STATE REGULATION OF INVESTMENT ACTIVITY
}

\author{
Rasha Bashar Ismail Al Sabbagh ${ }^{1}$ \\ ${ }^{1}$ Assistant professor, Shaqra University, Kingdom of Saudi Arabia, e-mail: rashasabbagh39@gmail.com
}

\begin{abstract}
In the article the basic principles of state regulation of investment processes in country, and the stimulation prospects of attracting investment into the economy are analyzed. The purpose of the article is to develop specific measures to improve public policy on investment and increase investment in the economy. The author used system method of scientific research, as well as method of analysis and synthesis. A necessary condition for attracting a sufficient amount of investment is a high level of investment attractiveness, which is based on the legal framework of state regulation of investment activities and the stability of economic processes. The tendencies of investment policy at the present stage of development of the economy and developed measures to support domestic producers, the preservation and growth of social and economic potential of the regions, providing expanded reproduction, stabilization and support economic growth are studied. The use of investment partnerships as an implement of state policy that will allow to use available economic resources of the country efficiently is offered.
\end{abstract}

Keywords: state regulation, investment activity, investments, economic growth, investment partnership, investment policy.

JEL Classification: H57, H82, K22, K33

Formulas: 0; fig.: 2; tabl.:0; bibl.: 5

Introduction. In the conditions of crisis phenomena in the sectors of economy, economic transformations should be aimed at reforming the existing economic mechanism, which should provide optimal conditions for all economic entities, reduce financial risks and maintain investment attractiveness of the industry and region. Therefore, in the formation of state regional policy it is necessary to develop measures aimed at supporting domestic producers, preserving and growing the socioeconomic potential of the regions, ensuring expanded reproduction, stabilization and support of economic growth.

Literature review. Problems of state regulation of investment activity are covered in the works of scientists, in particular, G. Birman, S. Brew, D. Darning, M. Jonko, I. Campbell, P. Lindert, D. Miller, M. Porter, S. Fisher and others.

Aims. The purpose of the article is to develop specific measures to improve public policy on investment and increase investment in the economy. A necessary condition for attracting a sufficient amount of investment is a high level of investment attractiveness, which is based on the legal framework of state regulation of investment activities and the stability of economic processes.

Methods. The author used system method of scientific research, as well as method of analysis and synthesis.

Results. The current conditions of economic development cannot provide a sufficient level of investment. Domestic investments are hampered not only by the development of the domestic stock market, but also by the state of the country's financial system, while the unstable political situation puts the problems of regulating the investment process in the background. The main factors that prevent foreign investment are: backwardness of infrastructure, underdeveloped raw materials, external debt, low credit rating, devaluation of the national currency, low consumer 
incomes, problems with repatriation of profits. All this creates a negative investment attractiveness, so the most important issue for the government should be to create comfortable conditions for investors [5].

Reducing the demand for products produced by producers requires the formation of new tools that will attract investment in the production process, aimed at using new innovative achievements, which will maintain and increase the competitive advantages of domestic producers. In the context of the economic crisis and budgetary constraints, the regulation of investment activity is characterized by the impact on investment by the state and organizations of professional market participants. The state can directly regulate and manage the direction, use and profitability of investments.

Therefore, an important point is to determine the degree of state participation in the regulation of investment activities and economic growth. To revive production, it is advisable to increase the regulatory role of the state in the economy, which will concentrate certain financial resources on technological modernization and reconstruction of production.

Cooperation between the state, economic sectors and the financial sector should be based on mutual agreements on joint investment activities and the distribution of results, which should be regulated by law. To ensure investment activity, it is necessary to determine the sphere of influence of the state and enterprises of the real sector in the investment process. It is also necessary to restore the potential level of aggregate demand and revive production activities through the recovery of monetary and financial systems, reduce income differentiation, in turn, the growing flow of investment can be aimed at improving the sectoral and reproductive structure of the economy. This in turn will benefit both the state and other investment entities.

The stabilization measures will lead to the strengthening of public financial policy, the formation of stable institutions of the financial system. Creating market conditions on this basis for the further formation of aggregate demand and for increasing investment, the purpose of which is to transform the sectoral and reproductive economy. In the process of activity, potential investment partners of structural adjustment are identified: the state, the industrial complex, the financial sector. The experience of forced industrialization or modernization of production in countries focused, in general, on the widespread use of market mechanisms in economic development is interesting. When considering the participation of the state in such transformations, it is important to "monitor" the quality and results of state intervention. Three factors are important: 1) the period that the economy is currently going through (the state of its productive forces, external conditions); 2) the infallibility of the course chosen by the state in these economic and political conditions; 3) the ability of economic entities to adequately respond to regulatory actions of the state.

A typical example of state influence on the development of production is the industrial policy of Japan in 1950 -1970, when two Japanese ministries - the Ministry of Finance and the Ministry of Industry and Foreign Trade directly controlled the allocation of resources for the steel industry, shipbuilding and technical industry as a 
whole. This kind of control was possible by maintaining the exchange rate of foreign currency and the interest rate below the equilibrium level, resulting in an artificial shortage of resources, which became the basis for their administrative distribution. But since the 70's state regulation of this country has become less pronounced [4].

Contradictory experience of state participation in the process of modernization of the production apparatus of Japan and the newly industrialized countries of Southeast Asia, and the contradictions in the evaluation of this experience allows us to determine the logic of this phenomenon. It consists in the fact that at certain stages of economic development the state apparatus has the opportunity to correctly determine the scale and direction of redistribution of resources. This may apply to cases where the correctness of the chosen tactics is confirmed by the experience of countries that have broken into the advanced (North America, Western Europe). The problem is only in what way (administrative, legal, economic or ideological) or a combination of what ways (administrative, legal, economic or ideological) to subordinate a clear state policy of other economic entities.

As we move faster than the leading countries, the uncertainty inherent in longterm investment increases. The generalization of the experience of leading countries is increasingly fragmented and, finally, catching up with countries approaching the limit where attempts to copy other people's development can lead to failures in economic development. At the same time, large-scale direct government regulation is then replaced by softer forms, increasing the role of market regulation [4]. This is due to the fact that with the country's entry into its own development trajectory (South Korea, Japan) the choice of the state apparatus of "key technologies" and "promising markets" is the main problem of future-oriented industrial policy and is associated with much more serious mistakes. than the same choice of the whole mass of independent companies, carried out by "trial and error" The actions of these companies cannot be replaced by "collective reason" even if the discussion involves various corporate groups.

Western economists are often skeptical of the Japanese Ministry of Industry and Foreign Trade or other similar government agencies, pointing out that there is no direct evidence to support the effectiveness of individual policies in industrial policy compared to what would be achieved through market regulation [1]. It is necessary to take into account the need for public policy, taking into account the dynamics of development of a country, the period experienced, world trends. Also, what is true for the United States, Britain, Germany, may not apply to Japan [4].

In determining the sphere of influence of the state on the process of structural transformation and the creation of a highly efficient economy it is necessary to use universal approaches that have justified themselves in world practice and approaches related to specific features of the country at the present stage of its development.

It is possible to determine the main directions of state participation in the investment partnership, which can be clarified or expanded in the actual organization of public-private partnership, namely the investment partnership. These include: development of general provisions, legal and economic foundations of the institution of partnership and relevant infrastructure; modernization and further development of 
production and social infrastructure; subsidizing promising research and development, which bring the economic structure of the country to the forefront; investment in human capital in order to develop innovative skills and improve the general skills of the workforce; management of financial flows at the macro level, setting up a mechanism for accumulating investment, etc.

Establishing the spheres and scope of state activity in structural transformations means that all other issues are resolved by other participants in the investment partnership (real sector and financial sector) independently within the general action program under the general coordination of the minimum number of investment partnership representatives. In implementing the idea of partnership, the main thing that can be achieved is to increase the level of trust in government policy and actions of partners towards each other.

The main task of the investment partnership is the efficient use of available resources of the country. As the efficiency of the use of production resources (land, labor, capital, entrepreneurial skills, etc.) and the involvement of previously unused resources increases, the return of each of them will increase. In parallel with this process, the growth of household incomes and an increase in aggregate demand is expected. This development is possible in a market economy, provided that there is a high level of public and business confidence in government policy. In this case, the aggregate supply curve will shift to the right and down as a result of lower production costs, while the aggregate demand curve will shift to the right and up.

It is assumed that it is in this development that the idea of investment partnership is possible. That is, an investment partnership is a complementary element in the set of factors that ensure economic growth. The task of the investment partnership is to ensure a qualitative shift in the efficiency of economic resources through close cooperation and common policies of the parties involved in investing in infrastructure and fixed capital of the real sector.

The organization of investment partnership and conditions of formation of investment partnership are presented in the form of schemes (fig. 1,2).

Economic growth is characterized by the attraction of additional production resources and new use of resources that were used previously. This is an intensive use of resources, or individual groups of factors of production, accompanied by a synergistic effect

A necessary condition for attracting an additional number of factors, or their reformation is the expansion of investment activity. Additional investments require additional financial resources, labor and resources

\begin{tabular}{|l|}
$\begin{array}{c}\text { Practically it is possible to carry out only in the presence of additional } \\
\text { accumulations or in the presence of subjects of investment activity of } \\
\text { the convincing bases for financing of the project }\end{array}$ \\
$\begin{array}{c}\text { The real increase in the scale of investment activity is carried out on the basis of a coordinated financial and } \\
\text { credit policy. Previously unused or irrationally used factors of production are involved. Lending is growing. } \\
\text { Loans are repaid on time and issued until the potential for expanded investment activity is used }\end{array}$ \\
to moderate interest rates and a \\
stable exchange rate
\end{tabular}

Figure 1. The basic conditions for the formation of an investment partnership 


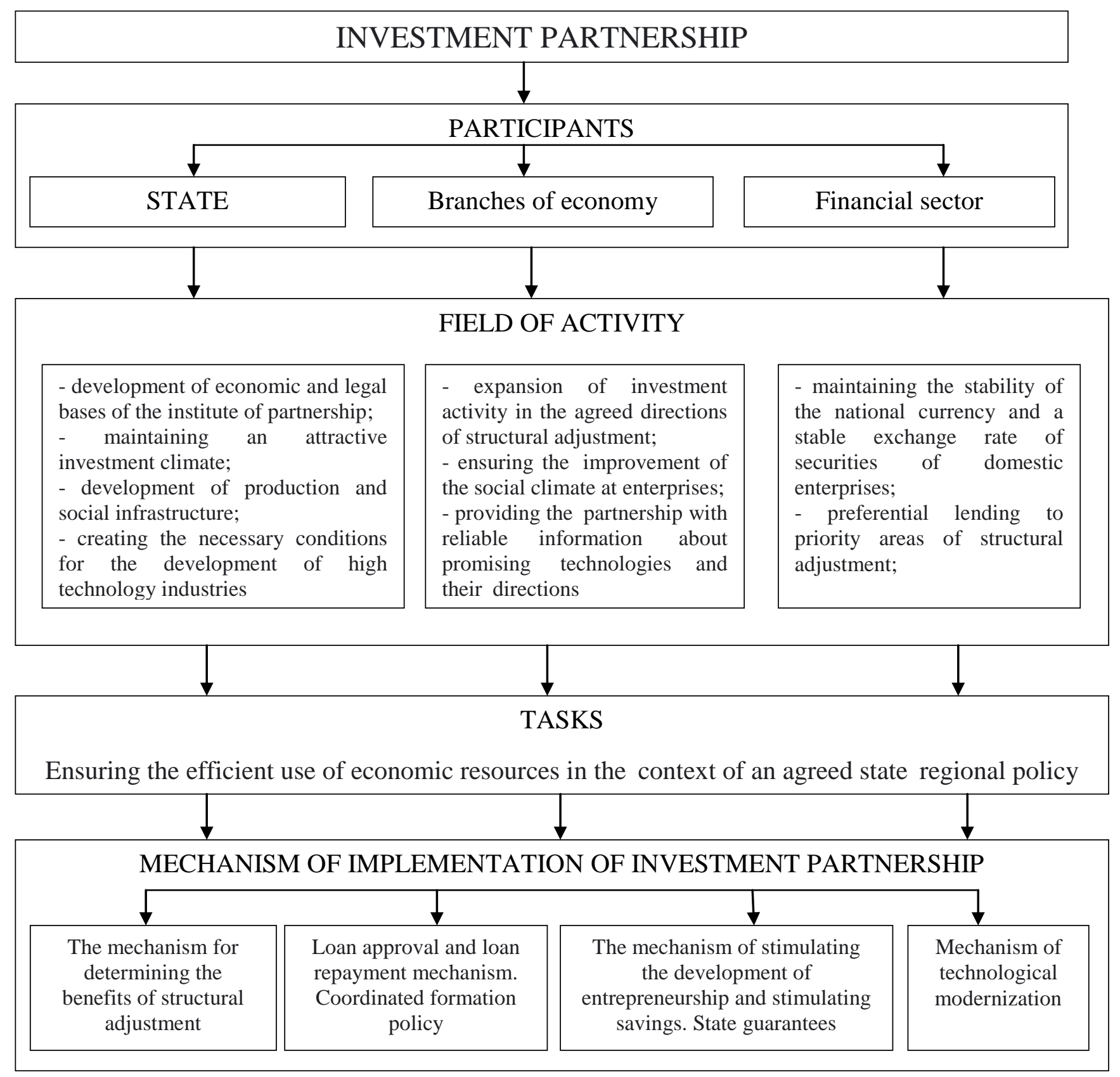

Figure. 2 The mechanism of investment partnership organization

Conclusions. The state should regulate the investment process and be responsible for its organization, as state support for investment activities of the investor helps to increase the investment attractiveness of the country. Therefore, the formation of investment attractiveness of investment objects requires, firstly, economic and political stability in the country and, secondly, a stable legal framework that will allow for sustainable and efficient operation of investment objects.

The use of investment partnership as a tool of public policy will allow effective use of available economic resources and increase the investment attractiveness of the country in a financial crisis. 


\section{References:}

1. Transnational Corporations: The International Legal Framework, UNLTNC, 205.

2. Bradlow D. and Escher A. (eds), 1999. Legal Aspect of Foreign Direct Investment.

3. Brewer T.L. and Young S. 1998.

4. Fernandez, P. and Bilan, A. 2013. 110 Common Errors in Company Valuations. International Journal of Economics \& Business Administration, 1(1), 33-78.

5. See 'CFIUS Annual Report to Congress' for CY 2019, available at https://home.treasury.gov/system/files/206/CFIUS-Public-Annual-Report-CY-2019.pdf. 